\title{
Right portal vein embolization by laparoscopic catheterization of the inferior mesenteric vein
}

\author{
Embolização percutânea da veia porta por acesso \\ laparoscópico da veia mesentérica inferior \\ Marcus Vinicius Martins Cury', Fernanda Mesquita de Brito Castro', \\ Lister Arruda Modesto Santos², Sandra Lucia Lodi Peres², Roberto Sacilotto
}

\begin{abstract}
Right portal vein embolization is often performed to prevent liver insufficiency after major hepatic resection. The procedure usually involves direct puncture of the portal vein, which requires hepatic hilum manipulation, and may be associated with liver injury, pneumothorax, and hemoperitoneum. This report describes a technique of laparoscopic insertion of a sheath into the inferior mesenteric vein followed by right portal vein embolization.
\end{abstract}

Keyword: cholangiocarcinoma; portal vein embolization; laparoscopy.

\begin{abstract}
Resumo
Habitualmente, a embolização do ramo direito da veia porta é realizada para prevenir insuficiência hepática após uma ressecção hepática estendida. Geralmente, este procedimento é realizado por punção direta da veia porta, resultando, ocasionalmente, em lesão hepática, pneumotórax e hemoperitônio. No presente relato, descrevemos uma alternativa ao acesso direto à porta, através da cateterização percutânea da veia mesentérica inferior com o auxílio da dissecção videolaparoscópica.
\end{abstract}

Palavras-chave: colangiocarcinoma; embolização de veia porta; laparoscopia.

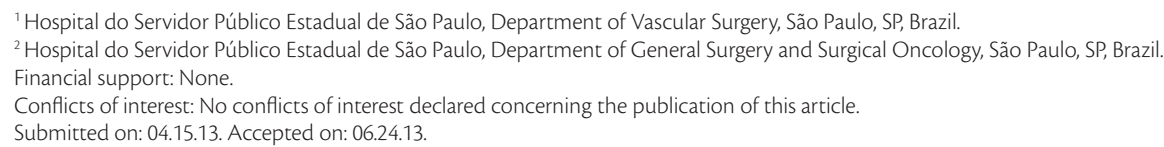




\section{INTRODUCTION}

Preoperative right portal vein (RPV) embolization is a safe and effective procedure to prevent postoperative liver insufficiency after major hepatectomy ${ }^{1}$. Its main outcome is hypertrophy of the non-embolized hepatic lobe, and it has been used during resection of liver metastases and in the management of hepatobiliary malignancies ${ }^{2}$.

RPV embolization is most often performed percutaneously, but this approach is sometimes associated with complications, such as pneumothorax, hemoperitoneum, and subcapsular hepatic hematoma ${ }^{3}$. Alternatively, portal vein access may be achieved via the ileocolic veins ${ }^{4}$.

This report describes the percutaneous access of the inferior mesenteric vein (IMV) with laparoscopic dissection followed by RPV embolization.

\section{CASE PRESENTATION}

A 62-year-old woman with diabetes, seen in an emergency department, presented with progressive jaundice, asthenia, and weight loss that persisted for 15 days. Laboratory tests revealed elevated levels of serum bilirubin and hepatic canalicular enzyme. Additionally, a computed tomography (CT) scan showed moderate intrahepatic and extrahepatic biliary dilatation, with no evidence of biliary calculus.

Because of the presence of progressive jaundice, the patient was referred to percutaneous transhepatic biliary drainage. Cholangiography revealed an extrahepatic compressive lesion, suggestive of Klatskin tumor. An 8.5 F external drain was inserted into the right and left biliary duct, which relieved the patient's symptoms. As the patient would have to undergo extended hepatectomy to treat the cholangiocarcinoma, preoperative portal vein embolization was scheduled.

With the patient under general anesthesia, her abdominal cavity was examined using laparoscopy. No metastases were detected, and the IMV was dissected. After isolating about $3 \mathrm{~cm}$ of the IMV, the laparoscopic pneumoperitoneum was slightly reduced. An $18 \mathrm{G}$ needle was percutaneously inserted into the left flank and advanced to the IMV. A $5 \mathrm{~F}$ sheath was placed (Figure 1), and direct catheter portography was performed (Figure 2). A 0.035" hydrophilic guide wire was advanced through the IMV to the portal vein. Then, a $5 \mathrm{~F}$ Berenstein catheter was advanced to the RPV branches, which were embolized with polyvinyl alcohol (100$300 \mu \mathrm{m})$, absorbable Gelfoam ${ }^{\circledR}$, and COOK Nester ${ }^{\circledR}$ coils. Final venography confirmed that the procedure

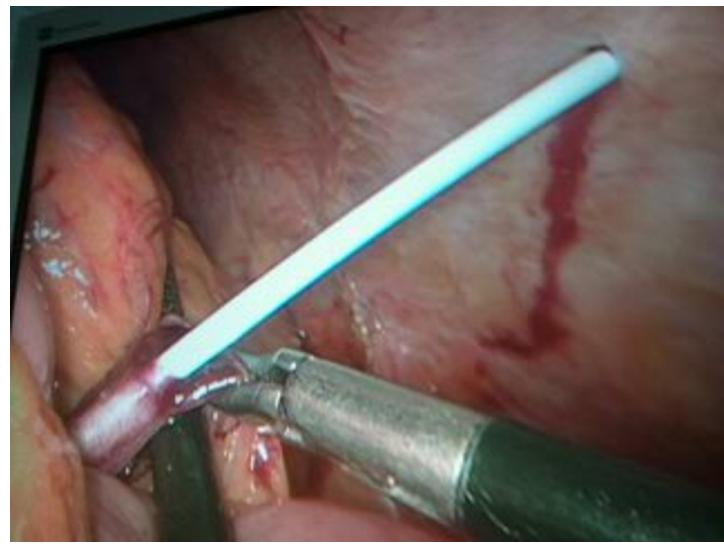

Figure 1. Laparoscopic dissection of the inferior mesenteric vein was followed by percutaneous catheterization.

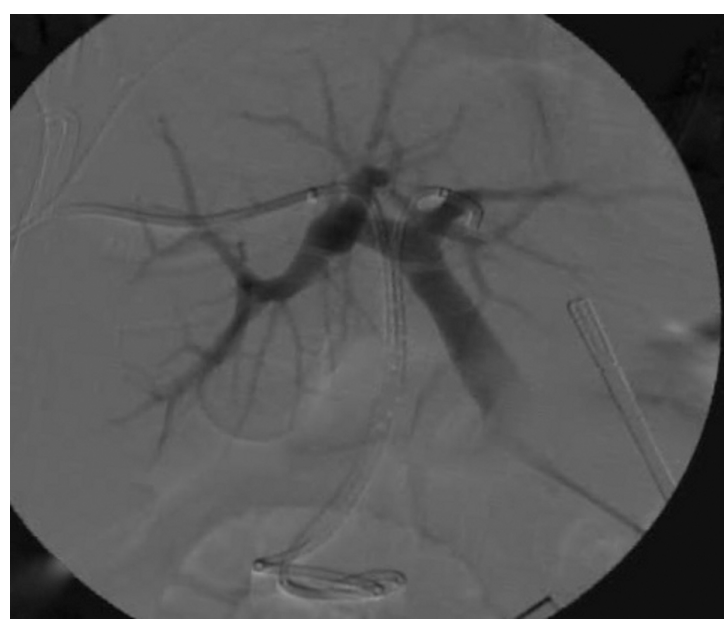

Figure 2. Direct catheter portography.

was successfully completed (Figure 3 ), the sheath was removed, and hemostasis was achieved by means of IMV clip ligation.

Eight weeks later, a CT scan revealed left hepatic lobe hypertrophy (Figure 4), and right extended hepatectomy (segments IV-VIII) was performed. Postoperatively, the patient had no signs of liver insufficiency. Unfortunately, she died 30 days after the extended hepatectomy because of catheter-related sepsis.

\section{DISCUSSION}

Several studies have evaluated the morbidity and mortality of RPV embolization before major hepatectomy. In a prospective study of consecutive patients, Abdalla et al. ${ }^{5}$ found no differences in mortality after hepatectomy between patients with or without preoperative RPV embolization. 


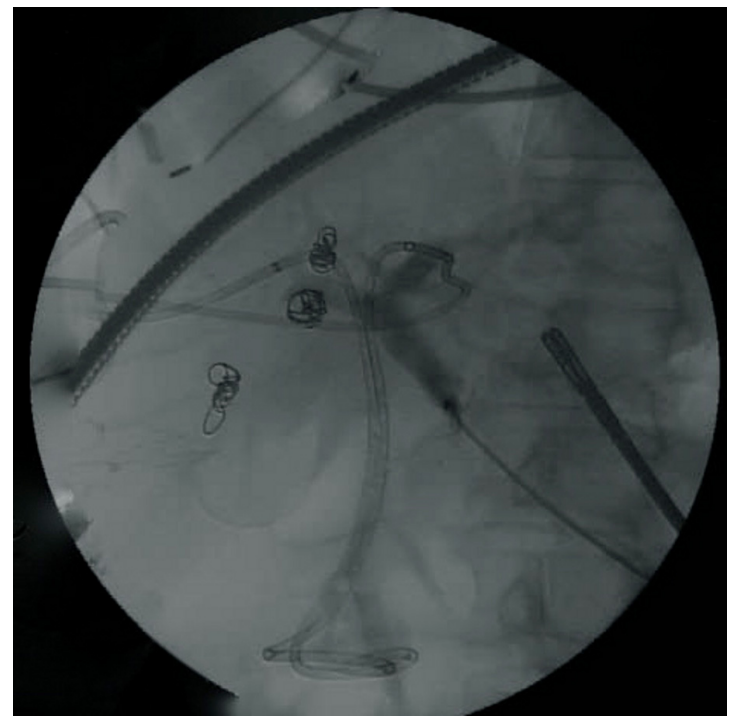

Figure 3. Right portal vein post-embolization with polyvinyl alcohol, absorbable gel foam, and coils.

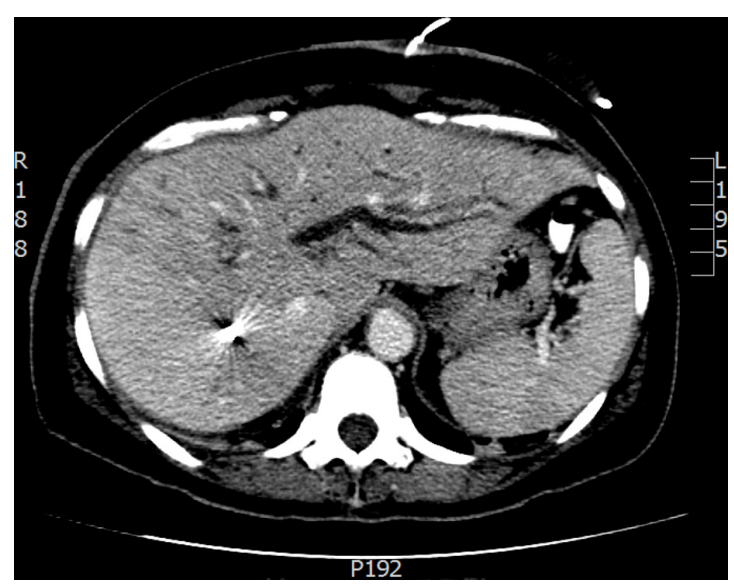

Figure 4. Computed tomography showing hypertrophy of the left hepatic lobe.

In another study, Hemming et al. ${ }^{2}$ also found no differences in postoperative mortality in patients with or without embolization. However, they reported that embolization was beneficial in patients whose estimated functional hepatic volume was $<25 \%$.

Despite these findings, Ebata et al. ${ }^{6}$ analyzed 494 patients with cholangiocarcinoma or gallbladder cancer and concluded that RPV embolization before hepatectomy was safe and beneficial. In a meta-analysis, Abulkhir et al. ${ }^{4}$ concluded that RPV embolization is effective, as it induced hypertrophy in a non-embolized liver lobe, increased functional remnant liver volume, and decreased postoperative liver insufficiency.
Surgical ligation of the RPV is an alternative method to induce hypertrophy without requiring embolization. This procedure was originally performed by Are et al. ${ }^{7}$ using a laparoscopic approach. They reported that the main advantages of this method were ease of evaluating the abdominal cavity and avoidance of hepatic injuries. Robles et al. ${ }^{8}$ conducted a comparative study between surgical ligature and embolization of the portal vein. They concluded that RPV embolization was more effective than surgical ligature in inducing liver hypertrophy, and that it increased functional remnant liver volume.

A no-touch technique has also been described for portal vein manipulation. Bueno et al. ${ }^{9}$ conducted a laparotomy followed by ileocolic vein catheterization, which resulted in successful portal vein clot fragmentation in pediatric patients with portal vein thrombosis after liver transplantation. Laparoscopic ileocolic vein dissection was also reported as an alternative to RPV embolization before major liver resection ${ }^{10}$.

In summary, we described an approach to laparoscopic dissection of the IMV as an alternative to RPV embolization. We believe that this approach decreases hepatic hilar injury and facilitates abdominal cavity evaluation for cancer staging.

\section{REFERENCES}

1. Makuuchi M, Thai BL, Takayasu K, et al. Preoperative portal embolization to increase safety of major hepatectomy for hilar bile duct carcinoma: a preliminary report. Surgery. 1990;107(5):521-7. PMid:2333592.

2. Hemming AW, Reed Al, Howard RJ, et al. Preoperative portal vein embolization for extended hepatectomy. Ann Surg. 2003;237(5):686-93. PMid:12724635 PMCid:PMC1514515. http:// dx.doi.org/10.1097/01.SLA.0000065265.16728.C0

3. DiStefano DR, de Baere T, Denys A, et al. Preoperative percutaneous portal vein embolization: evaluation of adverse events in 188 patients. Radiology. 2005;234(2):625-30. PMid:15591428. http:// dx.doi.org/10.1148/radiol.2342031996

4. Abulkhir A, Limongelli P, Healey AJ, et al. Preoperative portal vein embolization for major liver resection: a meta-analysis. Ann Surg. 2008;247(1):49-57. PMid:18156923. http://dx.doi.org/10.1097/ SLA.0b013e31815f6e5b

5. Abdalla EK, Barnett CC, Doherty D, et al. Extended hepatectomy in patients with hepatobiliary malignancies with and without preoperative portal vein embolization. Arch Surg. 2002;137(6):67581. PMid:12049538. http://dx.doi.org/10.1001/archsurg.137.6.675

6. Ebata T, Yokoyama Y, Igami T, Sugawara G, Takahashi Y, Nagino $M$. Portal vein embolization before extended hepatectomy for biliary cancer: current technique and review of 494 consecutive embolizations. Dig Surg. 2012;29(1):23-9. PMid:22441616. http:// dx.doi.org/10.1159/000335718

7. Are C, lacovitti S, Prete F, Crafa FM. Feasibility of laparoscopic portal vein ligation prior to major hepatectomy. HPB (Oxford). 2008;10(4):229-33. PMid:18806869 PMCid:PMC2518294. http:// dx.doi.org/10.1080/13651820802175261 
8. Robles R, Marín C, Lopez-Conesa A, Capel A, Perez-Flores D, Parrilla P. Comparative study of right portal vein ligation versus embolisation for induction of hypertrophy in two-stage hepatectomy for multiple bilateral colorectal liver metastases. Eur J Surg Oncol. 2012;38(7):586-93. PMid:22560404. http://dx.doi. org/10.1016/j.ejso.2012.03.007

9. Bueno J, Perez-Lafuente $M$, Venturi $C$, et al. No-touch hepatic hilum technique to treat early portal vein thrombosis after pediatric liver transplantation. Am J Transplant. 2010;10(9):2148-53. PMid:20887425. http://dx.doi. org/10.1111/j.1600-6143.2010.03236.x

10. Tsuge H, Mimura H, Kawata N, Orita K. Right portal embolization before extended right hepatectomy using laparoscopic catheterization of the ileocolic vein: a prospective study. Surg Laparosc Endosc. 1994;4(4):258-63. PMid:7952434.
Correspondence

Marcus Vinicius Martins Cury

Department of Vascular Surgery - Hospital do Servidor Público Estadual de São Paulo

Av. Pedro de Toledo, $1800,14^{\circ}$ andar, Vila Clementino CEP 04039-901 - São Paulo (SP), Brazil

Phone: +55 (11) 4573-8156

Fax: +55 (11) 4573-8374

E-mail: mvmcury@hotmail.com

Author's information

MVMC is MD, Vascular surgeon at Hospital do Servidor Público Estadual de São Paulo.

FMBC is MD, Vascular surgeon at Hospital do Servidor Público Estadual de São Paulo.

LAMS is MD, General \& Surgical Oncology at Hospital do Servidor Público Estadual de São Paulo.

SLLP is MD, General \& Surgical Oncology at Hospital do Servidor

Público Estadual de São Paulo.

RS is PhD, Vascular surgeon at Hospital do Servidor Público Estadual de São Paulo.

Authors' contribution

Conception and design: LAMS, MVMC Analysis and interpretation: SLLP, MVMC

Data collection: FMBC

Writing the article: MVMC, RS

Critical revision of the article: SLLP, RS

Final approval of the article*: MVMC, FMBC, LAMS, SLLP, RS

Statistical analysis: N/A

Overall responsibility: MVMC

Obtained funding: None.

*All authors should have read and approved of the final version of the article submitted to I Vasc Bras. 